\title{
8 Alternative views of the future of quality assurance and evaluation
}

\author{
Johanna Kallo, Tuomas Takala, \\ Vera Gorodski Centeno, and Olli Suominen
}

\section{Introduction}

In this chapter, we analyse the views of Brazilian, Chinese, and Russian actors concerning the future development of quality assurance and evaluation. Our interest is in examining actors' perceptions within a wider historical and political context, with the aim of comparing the possible futures of QAE in the three case countries. The chapter complements the findings presented in previous chapters by focusing not only on past experiences but also on the future aims which guide present policies and action (see Adam 2010; Andersson 2012; Andersson \& Rindzevičiute 2016). By looking at the future goals set for education QAE, we aim to advance research into one of the book's key themes, namely, how QAE policies shape education practice and discourse.

We draw on critical futures studies (Bussey, Inayatullah, \& Milojevic 2008; Ogilvy 2004), which perceive the future as a site of alternatives, instead of attempting to predict it. Moreover, we subscribe to the argument that the task of the research on possible futures is not only to contour the unknown but to rethink the structures of power and governance embedded in official future scenarios and forecasts (Cruz 2015; Inayatullah 1990, 2002; Slaughter 2002). These ideas are related to the theoretical notions of complexity referred to in the book's earlier chapters, one of their key themes being the future's unpredictability (Biesta \& Osberg 2010; Cairney \& Geyer 2015). Predicting the future of complex systems is difficult, which is why researchers who recognise this challenge refrain from definite forecasts and focusing on alternative future images and scenarios. The idea of alternative futures is also reflected in this chapter's title, which refers to the differing perceptions arising from the research data.

Investigating the future as a site of alternatives helps in grasping a picture of large political changes and identifying patterns in current political action affecting the future (Cruz 2015). It also helps in understanding what future perspectives become hegemonic over others and why. The fall of socialist utopias at the turn of the 1980s and 1990s, for example, created room for the rise of a neoliberal, globalised, and technologised view of the future (Milojevic 2005). This neoliberal thinking grew stronger until the recession of the 2000s, after which criticism of the social disadvantages caused by neoliberal economic policies increased, particularly in Latin American countries (Coronil 2011). 
We agree with Masini (1993) that views of future and time are strongly linked to their surrounding cultures and traditions. Several factors, such as experience, and varying philosophical and political traditions and systems, underlie the differing perceptions of the future in our case countries. An understanding of these differences requires knowledge of the countries' own traditions, as these belong to the collective memory affecting present politics and future development (Hoffman 2013). Moreover, some elements of views of the future may have evolved over a long period, and sometimes visions which had little impact originally may have become mainstream (ibid.). This finding is related to the idea of path dependence and increasing returns, where large consequences may result from relatively small or contingent events (Pierson 2000).

The first chapters of this book comprehensively described our project's data. Here, we need to point out that not all the interviews conducted for the project referred to the future. The analysis for this chapter is based on selected national-level interviews in which such references were made: Brazil $(\mathrm{n}=22)$; China ( $n=15)$; and Russia ( $n=11)$. With this number of interviews, we of course cannot claim to demonstrate "how educationists in general in Brazil, China, and Russia think about the future of QAE", but our data allow us to reveal the qualitative range of their opinions. In addition to the interview data, we examine the latest plans for education, and especially QAE, put forward in each case country.

Our interview data on the possible futures in the three countries may be characterised as follows: in Brazil, interviewees openly expressed their personal, rather than organisational or official, views, whereas in China and Russia possible futures were mentioned relatively rarely by our interviewees, and such views were expressed in response to questions prior to the explicit futures question at the end of the interview. To some extent, such views have already surfaced in the analyses reported in the book's earlier chapters. As this chapter's analysis shows later, notions of what constitutes "quality of education" and views on QAE are closely interlinked: different conceptions of quality have implications for how quality can and should be evaluated, and conversely, different tools of QAE either prioritise or downplay different notions of quality.

We continue with a review of the changing perceptions of time and future from an historical perspective, including the archetypes of the future of education developed by Inayatullah (2008). Next, we focus on an analysis of the case countries by briefly considering the domestic economic, political, and ideological factors which may affect actors' views of the future development of education QAE. Thereafter, we use our interview and documentary data to analyse how actors in these countries perceive the future trends of QAE in their respective contexts.

\section{Changing concepts of time and different archetypes of the future of education}

Barbara Adam (2010) presents a substantial analysis of how human perceptions of the future have evolved. The earliest conceptions emerged and evolved within religious mythologies which determined the world's future direction 
and the human being's life course. The annual rhythm characteristic of natural economies reinforced perceptions about the cyclical nature of time and the recurrence of the past in the future (Adam 2010). The development of science and technology and the rise of the idea of linear progress represented the fall of myth; the idea of progress guided the search for better utopias and challenged religious providence. People now believed they could influence the future and that they could remould it to suit their needs. The calendar enabled more precise planning, which led to an increase in control, social synchronisation, and regulation. At the same time, paradoxically, the future became more uncertain and contingent, as previously unchallenged traditions of the past ceased to provide answers to future problems (Adam 2010; Ogilvy 2004).

The belief in constant progress has met increasing criticism in recent decades. Ecological devastation, global economic crises, and the failure of socio-political utopias has strengthened the post-modern view that the world and its future cannot be explained by relying on the idea of progress (Adam 2010; Milojevic 2005; Ogilvy 2004). Adam (2010) notes that the future should no longer be considered a "void"; she finds the idea of a conjecture or an "open future" flawed, as present and past generations, through their irresponsible exploitation of nature, have already imposed limits for future generations. Ogilvy (2004) even describes the present enthusiasm for predicting possible futures - various, often conflicting scenarios and future visions - as tragi-comic.

Current prospects, as Milojevic (2005) states, tend to fall into two categories: a firm belief in continued technological development or anxiety about ecological regression leading to natural disaster. However, she cautions against succumbing to such binary utopian or dystopian views. We agree with Milojevic's view that instead of taking a binary approach to the future, it should be considered a heterotopy, where many different, often competing, visions exist simultaneously. These visions are related to values and are continuously negotiated, locally and globally. What some mean by utopia may thus mean dystopia to others.

The theory facilitating this chapter's analysis is Inayatullah's (2008) "futures triangle" and the five archetypal images of the future and the position of education which accompanies it. The futures triangle maps the future in three dimensions: the weight of history, the pushes of the present, and the pulls of the future. Examining historical trajectories in futures research is important, as many of the existing deep structures set the boundaries of future action and change. Likewise, identifying existing trends is important because some of these trends continue and have an influence far into the future. The archetypal images of the future are those which pull people forward (Inayatullah 2008). The archetypes of education futures were inspired by the tradition of research into various future archetypes (see Cruz 2015) and developed in a series of workshops. Although the archetypes are different, they share a common feature in their criticism of the existing education system (Milojevic 2005).

The first archetype believes in constant progress and evolution. It is characterised by a modernist and industrial vision that education should provide basic skills such as mathematics and training for the needs of the economy and the nation-state; it should train consumers, workers, and citizens. 
The second archetype is the opposite of the first and cautions against the collapse of humanity which people will inevitably cause in their continuing excessive exploitation of nature. Humanity has overshot its limits; the future will be worse than the present. This archetype portends growing inequalities among people and deteriorating future conditions. Current education and training provide no remedy for social problems and do not meet a changing world's needs.

The third archetype is idealistic: the world manifests itself as a garden, "Gaia", where cultures are flowers and people's inequality can be socio-technologically fixed. This requires changes in education and training; education institutions should transform themselves from silos of instruction into ecologies of learning pedagogies. Education is idealistic; schools and universities become gardens where students focus on finding their unique skills and learning from each other.

The fourth archetype is globalism: when borders fall, free movement of technology and capital will bring wealth to all. This archetype is opposed to traditional "isms" and dogmas, which it considers as barriers preventing people from achieving a new world. Education prepares individuals for the world of global technology, in which new technologies, global corporations and businesses, and non-governmental actors define frames of reference and rules of action.

The fifth archetype constitutes a counterbalance to the other archetypes by addressing the future nostalgically. A simpler way of life lies ahead, with a clearer hierarchy and less disruptive technologies. The best days have passed, and the changes of the present are too overwhelming. Education should therefore return to its fountainheads, which are filled with basics focusing on morality, clear gender roles, strong leadership (often male), and communitarian values.

In the following section, we apply the futures triangle and the idea of the five archetypes to a reflection of our analysis of QAE in Brazil, China, and Russia. We are especially interested in whether any of these archetypes manifests itself in the country contexts. Based on previous research, we first analyse the historical and political factors which have affected images of future education and QAE development in the three case countries. We then examine how the actors interviewed for this study see the possible future trends of QAE. We also consider the possible futures expressed in the latest national plans for education. These are the National Education Plan 2014-2024 (PNE) in Brazil, the Outline of China's National Plan for Medium and Long-Term Education Reform and Development (2010-2020), and the State Programme for Education Development in Russia (2013-2020).

\section{Perceptions of the future of QAE in Brazil, China, and Russia}

\section{Brazil: education as a national commitment}

\section{Historical weight and pushes of the present}

In Brazil, the contemporary period is felt by many as a transitional stage to the future (Coronil 2011). However, this societal sense of "being in transition" 
is not new. The Brazilian narrative has always depicted the present as a step into the future rather than a continuation of the past or a moment of its own. A few examples of recent official discourses under democracy clearly illustrate this constant reference to an abstract future: in 2011, the legacy of Cardoso (1995-2003) was characterised as "sowing the future" (Graziano 2011); in 2013, ex-President Lula da Silva (2003-2011) told a group of French entrepreneurs "there is no other country with the perspective of the future that Brazil has" (Silva 2013); in 2014, ex-President Rousseff (2011-2016) said that "education is our passport for the future" (Rousseff 2014); in a recent event called "Project Brazil Future", President Temer (2016-present) presented some economic ideas drawn from a programme called "A Bridge for the Future" (n.a. 2015).

Although opinions diverge (Braathen \& Kasahara 2015), Brazil has always characterised itself, and also been characterised, as the land of the future (e.g., Zweig 1941). Early Brazilian history is associated with colonialism and its later history with agrarian oligarchies and dictatorship, which provided no pertinent model for present or future action. The building or fostering of transitional stages to the future through a - frequently rhetorical - discursive construction may be understood as an inherent strategy to discursively break with history. Transitional stages channel attention and effort towards the construction of a better or promising future. This confidence in the future forms part of a set of societal dynamics and socio-cultural features which emerged in, took form in, or permeated Brazilian education history. These shaped the current views of the future in education, as the next section shows.

The Brazilian future has been constantly imagined in connection with the country's socio-economic development. Throughout the twentieth century, a focus on industrialisation, modernisation, and growth permeated every government's political project regardless of its political stance, albeit differently. Although the main goal of these development plans was to attain socioeconomic progress, they always included education concerns, and changes progressively occurred in schooling despite the huge gap between political intention and action. This close discursive connection between education and socio-economic progress allowed education to remain on the political agenda in times of both democracy and dictatorship. Despite the political discontinuity, the democratisation of education, seen in the concrete expansion of education opportunities, continued (Oliveira \& Araujo 2005; Klein 2006; Oliveira 2007; Gouveia \& Souza 2013).

However, the universalisation of education progressed very slowly. There was always significant political interest in education in Brazil, and policy decisions were always based on political rather than public policy reasoning. Governments tended to favour their own political base (Plank 1990) and undertake development plans which reflected these political interests; the place of education in public policy mirrored the political power of the time, which influenced the allocation of public resources to education development (Wjuniski 2013). Education has developed according to governments' ideological stances and political interests (Fonseca 2009). Although the level of political discontinuity was not drastic in the education policies of the last three democratic 
governments (1995-2016), civil society and scholars alike pointed to discontinuity at the level of concrete programmes as a major problem in Brazilian education (e.g., Zarpellon 2011).

Besides governments' own political interests, there have always been ideological and political differences across sectors, political levels, and the country. In the past, although clearly favouring specific societal groups, governments sought certain political compromises (Saviani 1996). Recently, governments have continued this path of seeking compromise through the fostering of democratic forums in which education plans and programmes are discussed. The most important are the National Conferences of Education (CONAE), which gather more than 3,600 participants. The current National Education Plan 2014-2024 (PNE) was outlined in the 2010 CONAE, ratified by the 2014 CONAE, and thereafter legislated. The PNE is thus the result of a broader democratic commitment, which explains its broad acceptance across the education arena.

As Chapter 3 explained in detail, the PNE endorses the use of QAE to achieve quality in education (Brasil 2014; Brasil, MEC/SASE 2014). This largely entails large-scale assessments, as students' performance is considered an important indicator in quality evaluation. The Development Index of Basic Education (IDEB) is perceived as the main Brazilian education quality indicator, and the PNE has restated the IDEB's target of meeting the Organisation for Economic Cooperation and Development's (OECD) Programme for International Student Assessment (PISA) mean score by 2021. Despite the primary focus on indicators, the PNE also envisages other QAE practices. The most significant is a new method of calculating the education budget which regulates the amount spent per student and per year for assuring the minimum standard of quality education (see Centeno, Kauko, \& Candido 2017). This alternative method requires a substantial increase in education funding.

\section{Perceptions of the future}

Inayatullah's archetypes (2008) help in defining Brazilian views by opposition; it explains views which do not seem to belong to the Brazilian culture. This section shows that "collapse" no less than "back to the future" seems far from adequate in defining the Brazilian approach to manifesting or perceiving the future. Neither disenchantment with education nor nostalgia plays a role in the views expressed by Brazilian interviewees. On the contrary, education is now, as always, an important socio-political project whose aims are both individual fulfilment and the country's progress.

Indeed, interviewees were quite hopeful about the future while acknowledging difficulties and limitations. One interviewee aptly remarked that the Brazilian narrative had always been one of improvement (BR-NNGO-04). Most interviewees mentioned the ongoing democratisation of education in Brazil - the progressive focus on school access, dropout and retention rates, and recently on school quality - to justify their confidence in continued future improvement. 
Where recent developments were concerned, they mentioned two favourable factors as crucial for the improvement of education quality. These were the auspicious socio-historical moment and the appropriateness of the PNE. The interviewees considered that the early 2010s represented an auspicious moment for the tackling of education reform. The huge attention paid to education and the concomitant engagement of every sector and level of society in the education debate provided an excellent basis for improving education policy and practice. One interviewee concisely summarised this in saying that in the Brazilian imagination, education would save the country (BR-N-09).

All interviewees viewed the PNE very positively, and all considered it the product of unprecedented collective understanding and commitment. They approved of the PNE's goals and targets and maintained it provided the necessary framework for Brazilian education. Regardless of their room for action or professional profile, all interviewees declared that Brazil had now clearly and correctly defined its education problems and solutions and the paths and directions which should be followed.

Interviewees expressed their views of the improvement of education quality in general; they did not focus only on QAE improvements. QAE was mostly linked with large-scale assessments, which in turn were connected with learning attainments. In their eyes, national evaluation, and the consequent indicators and indexes, belonged to a larger framework, whose main goals were the improvement of education quality and the enhancement of pupils' learning. The intensity or frequency of the relationships articulated between QAE and education quality varied - as might be expected - according to the interviewees' room for action: the more individuals were involved in QAE practices, the more their narrative swung towards the significance of this relationship. Thus, while those in charge of large-scale assessments tended to emphasise QAE, those with no direct connection with QAE practices tended to make only brief narrative incursions into the topic.

What may be unexpected is that, despite criticising the Evaluation System of Basic Education (SAEB) and related indicators and acknowledging its limitations in assessing education quality, all interviewees considered the existing QAE instruments to provide an adequate picture for monitoring quality and equality in Brazilian education. Many considered that it also provided valuable information to guide education practice and education quality improvement policy.

However, QAE practices were mentioned less than other factors connected with education and school quality. Interviewees addressed concrete education developments and tended to elaborate their views based on concrete examples, while addressing broader developments, such as the universalisation of school access, the reduction of inequality, and the need for change in school and teaching culture. In referring to more concrete goals perceived as more attainable, interviewees linked their views to learning achievement and education equality across the country, democratically consolidated and sustainable political processes, appropriate education policy and practice, school conditions, teacher training, working conditions, and teaching quality. 
In brief, QAE practices were only one of many factors interviewees mentioned. Many answered in a quite utopian tone, referring to major or encompassing abstract socio-political and even cultural changes. These references simultaneously conveyed their utopian and dystopian views. One interviewee clearly expressed this by mentioning that numbers helped to identify the "nonlearning" and the dropouts, to whom Brazilians should show no tolerance (BR-N-03). However, this interviewee concluded that this was a dream, corresponding to an education system in which everyone from the school to the federal government committedly fulfilled their own role.

Interviewees' dystopian views were largely linked to a lack of political conditions and real collective agreement on the implementation of practical measures which addressed quality and equality in such an enormous and diverse country. The political discontinuity and divergent positions and views which have converged in the PNE's formulation continue to diverge in its execution. Another common feature mentioned was the slow pace at which changes have occurred and reality has been impacted. Interviewees mentioned that improvement would continue to occur as it had in the past, despite economic and political cycles. However, they foresaw a return to a very slow pace of change.

\section{China: education as a means of rejuvenating the country}

\section{Historical weight and pushes of the present}

In China, future visions bear complex semantics inherited from the traditions of philosophical thinking in ancient and imperial times. Hoffman (2013) provides an interesting analysis of how images of the future have changed in China and the effects these changes have had on today's discourses. She points out that different concepts of time have been intertwined and manifested in various ways throughout Chinese history.

Confucian philosophy, which originated around 500 BCE, was founded on a linear concept of time and believed that the future was secured when people, led by rulers and officials, lived up to the highest ethical standards. Confucian teachings proclaimed that the golden age had passed and the imperial rulers should therefore always look to the past in reforming the state. This eventually led to the end of the imperial era, because it provided no tools for the state's regeneration. The new republican government sought influences from the West, providing an impetus to a discourse on the importance of external influences which has continued to this day (Hoffman 2013).

The Chinese Communist Party's assumption of power in 1949 represented a profound change in China's history and its conception of the future. The dismantling of archaic traditions and the later inception of reform became priorities. Mao Zedong's utopian projects, such as the Great Leap Forward and the Cultural Revolution, underlined this approach (Hoffman 2013). Since the late 1970s, China has pursued modernisation without abandoning the one-party 
system. Modernisation, prosperity, the reduction of regional disparities, and the safeguarding of the country's social cohesion have guided Chinese thinking about the future in the last three decades.

China is considered to be standing at a crossroads. The aspiration to influence future development through five-year plans, legislation, and long-term outlines guide societal policies and decision-making (Yang 2014). Futures research is popular and is closely linked to political decision-making and debates. The public approach to the future is generally optimistic, arising from the oneparty system (Callahan 2016). However, the population is ageing, the country's economic growth has slowed, and growth in military spending is the world's largest. The highly educated urban middle class faces a crisis caused by rising prices, and the countryside cannot provide meaningful work. People are weary of the idea of "growth first" (Hoffman 2013).

Current official thinking about the future is crystallised by the Communist Party's slogan the "China Dream". This official future vision was originally presented in a book by Colonel Liu Mingfu, and President Xi Jinping subsequently used it in his inauguration speech. Xi's China Dream seeks the return of China to its natural position as one of the world's leading states, a reference to the country's imperial status in the nineteenth century, when China accounted for about one-third of the entire global market. The Chinese Dream implicitly sees China superseding the USA as the leading economy by 2035. The aim is also to build a moderately prosperous society by the Communist Party's centenary in 2021. Concrete goals are the doubling of gross domestic product, $60 \%$ urbanisation, the building of a space station, and the blueprint for the One Belt One Road Initiative. The Chinese Dream differs significantly from previous harmonious visions of the Chinese future: it is seen more Sinocentric in its endeavour to consolidate China's position internationally (Callahan 2016). Confucianism has enjoyed a robust revival in this wave of nostalgia (Deng 2011).

Hoffman (2013) notes that the China Dream is a vision not of individuals but of the state. She describes how, alongside the formal vision of the future, a vision of the "Chinese Dream" exists which centres on constitutionality, freedom, and democracy. However, although some academic circles and public blogs discuss this vision, it is the view of few Chinese. Moreover, many different influences from ancient and recent history are also present in current Chinese thinking: in recent decades millions of Chinese have turned to spiritual traditions to navigate the future (Hoffman 2013).

\section{Perceptions of the future}

Education, together with science and technology, has become the key means for the restoration of China's leading global position (Postiglione 2015). The idea of rejuvenating the country through science and education was inherited from the Deng Xiaoping era of the 1970s and 1980s and strengthened during Jiang Zemin's presidency in the 1990s and early 2000s (Yang 2014). The idea that education is a means to rejuvenate the nation is also incorporated in 
the Preamble of the Outline of China's National Plan for Medium and Longterm Education Reform and Development (2010-2020) (hereafter "Outline"; $\mathrm{Gu}$ 2010). This document covers every level of education from pre-school to higher education and was created in cooperation with the OECD, the World Bank, and other international actors ( $\mathrm{Gu}$ 2010). Shanghai's participation in PISA 2006 also provided information for the Outline's preparation (Baird et al. 2016). The document contains several recommendations intended to enhance the quality assurance and evaluation of education.

The Outline includes several strategic goals, two of which are the equality and quality of education. These resemble the main themes of PISA (see Schleicher \& Zoido 2016; Gu 2010). The Outline states that the quality of education should be improved through several measures, such as the reduction of students' workload and the establishment of state standards for urban and, whenever possible, rural schools (Gu 2010; Outline 2010-2020). Subsequent studies have highlighted how the Outline strives for policies which reduce gaps between urban and rural education provision and encourage a transformation from exam-oriented to quality-oriented education (e.g., Yuan 2013). The Outline has boosted curriculum reform, which is a concrete tool for improving the quality of education (Xin \& Kang 2012).

A closer examination of the Outline reveals a contrast between quality education and the measures which guarantee it. The document paints a picture of an expanding monitoring and evaluation apparatus. It stipulates that teachers' qualifications will be improved, teacher recruitment will follow rigorous practices, and the development of evaluation will be continued by setting scientific and diverse benchmarks. Diverse evaluation approaches which help to promote students' development will be explored, student records kept, and the assessment of comprehensive quality developed. Attention is paid to the quality of the supervision system. The Outline stresses that mechanisms for effective supervision at all levels will be established and that schools should "willingly accept and cooperate with legislatures at all levels in supervision and inspection of education law enforcement, and with the personnel sent by law-enforcement agencies on supervision visits" (p. 43).

Actors interviewed for this study were moderately critical but also optimistic concerning future education reform. Some interviewees noted that the lack of independent evaluation authorities and supervisors' lack of expertise slowed the development of quality education. The improvement of supervision was important because supervisors should "possess a capacity to put forward plans to improve schools in the future" (CN-E-07). Some interviewees were critical of education reforms as generally insufficient and focused only on minor structural changes. They anticipated a deepening of urban and rural inequality if thorough measures were not undertaken. Old traditions such as the influence of students' socio-economic background on school choice were deeply rooted in the education system. The greatest challenge lay in the reform of antiquated approaches to learning. 
For the optimists, China's economic and technological development provides the necessary resources to ensure the implementation of evidence-based education and training reforms. Interviewees highlighted the importance of recruiting qualified teachers, the development of teacher training, and the move from exam-oriented education to an emphasis on the child's overall development. Some interviewees placed much trust in the National Assessment of Education Quality (NAEQ); this assessment was believed to enhance the monitoring of not only the teaching and learning process but also results - essentially a control of quality. In this respect, the NAEQ resembles a (social) technology which is believed to solve quality problems in remote areas as well (see Baird et al.2016).

Although interviewees' opinions on the need for reform seemed harmonious, they differed concerning the pace of measures. Some pointed out that swift political approaches were needed if the disparities between rural and urban areas were not to continue to deepen. Schools are already undergoing "a quiet revolution" (CN-E-07), in which ongoing curriculum reforms aim to reduce students' workload, especially in repetitive memorisation or drilling, and to enhance students' self-regulation and creativity in learning, as PISA encourages (Blackspear 2012; Baird et al. 2016). Other interviewees felt such a fast pace of reform was unrealistic. There were, as one interviewee noted, several factors which might slow the implementation of future QAE reforms, such as challenges related to the decentralisation of the education administration and its separation from the supervision system (CN-E-03).

\section{Russia: appreciation of the national pedagogical tradition and ideas for new development}

\section{Historical weight and pushes of the present}

The historical milestones of Russian futures research are found in the Bolshevik Revolution of 1917 and the dissolution of the Soviet Union in 1991. The Bolsheviks brought a strong future orientation to the Soviet Union's social policy. At its core was Soviet Communism's teleological eschatology, in which the idea of a utopia built by workers led all political activity. Future studies focused on making predictions and assumed an increasingly ideological hue during the Cold War (Bacon 2012).

The collapse of the Soviet Union brought the breakdown of the foundations of Soviet futures research. Although predictions of the Soviet Union's demise abounded during the Cold War, future studies within and outside the country failed to accurately predict the state's collapse. Bacon (2012) describes how futures research worldwide reached its nadir, failing to anticipate the dissolution of the Soviet Union and subsequently of the East European Bloc of socialist countries. In the years which followed, linear predictions were abandoned and interest in multiple scenarios increased. In the last two decades, more than ten divergent scenarios of the future of Russia have been 
constructed, reflecting the political issues which emerged at the time of their drafting (Bacon 2012).

Historical traditions and political changes have contributed significantly to how the future is understood in Russian daily life. According to Schilling (2008), many factors have influenced how Russians perceive their future. These include administrative arbitrariness, a high degree of power distance, late industrialisation, and wide geographical extension. A governance culture in which strategic decisions can be made in a tsarist fashion beyond legislative influence has shaped public views in a direction which makes people feel incapable of influencing their futures (Schilling 2008). Despite late industrialisation, the socialist economy was based on the production of detailed and centralised five-year plans, which were usually over-ambitious. Based on anthropological research, Yurchak (1997) has called the prevailing attitude towards the state's policies "non-involvement and simulated support".

In Russia, official views and presumably also popular thinking about the future have significantly changed since the collapse of the Soviet Union. The socialist utopia has been replaced by various scenarios, the contents of which vary significantly (Bacon 2012). A key feature of Russia's current domestic policy has been its division into conservative or Westernised positions, depending on attitudes towards foreign models and external influences (Johnson 2010). This division has also had implications for perceptions of the future and their interpretation. For example, Russia's political initiatives in recent years, such as proposals for closer cooperation with neighbouring countries, have been interpreted as nostalgic and conservative efforts to restore Russia as the world power it was during the Soviet period. However, as Krickovic (2014) reminds us, analyses of Russian policy should not succumb to overly narrow explanations, because there are many other political factors apart from nostalgia behind recent political initiatives in Russia, such as the unstable international situation, which impels Russia to seek new partners.

Current domestic policy embodies a deep-seated dualism which is significant for Russia's future development. Views are divided between those who advocate sympathy for Western values, European reform, and globalisation and those who see the increasing internal pressure for reform arising from globalisation and Europeanisation as a threat to Russian sovereignty (Johnson 2010; Pavlova 2010; Morgan \& Kliucharev 2012) - a similar division was already a key element in political and cultural debate in pre-Soviet Russia. In Chapter 4, we noted that the influence of international organisations on Russian education policy was relatively limited in the early post-Soviet years and has more recently become even less significant. At the same time, communication between Russian and foreign QAE experts has grown.

Tensions in political decision-making have also affected education policy and its vision for the future. Pavlova (2010) notes that the strategic goals to improve the quality of education and the idea of education as the key to socio-economic development outlined at the beginning of the millennium have never been questioned. However, the dualism mentioned earlier has resulted in a situation 
where goals created at the beginning of the millennium for the development of education and strategies based on them have become a hybrid including both traditional and modern goals, the latter influenced by Western values (see Boguslavskii \& Lelchitskii 2016). As the next section demonstrates, such dualism is reflected in views of the future of QAE.

\section{Perceptions of the future}

The State Programme for Education Development, 2013-2020, is a 700-page document covering all aspects of federally regulated education policy. The programme's overall aim is "to ensure that the quality of education meets people's changing requirements and the development objectives of Russian society and economy". The document outlines a comprehensive and uniform system of QAE based on the "principles of openness, impartiality, transparency, and public and professional involvement". This system will comprise the existing national examinations after grades 9 (the State Final Attestation, SFA) and 11 (the Unified State Exam, USE), and the procedures of independent quality evaluation. The information provided by these national tools will be complemented by Russia's continued participation in international assessments (PISA, Trends in International Mathematics and Science Study (TIMSS), and Progress in International Reading Literacy Study (PIRLS) (Government of Russia 2012: p. 218).

In general, in our comprehensive interview data from Russia, national-level interviewees were more outspoken on the issue of the desired futures of QAE in education, and views on this topic diverged more than they did among interviewees at the local level (the latter are not analysed in this chapter). Many respondents personally indicated that they valued the Soviet and pre-Soviet pedagogical tradition or referred to extensive media discussion of this topic. In this tradition, important elements of QAE are the strong professional autonomy of teachers in the assessment of their students and an emphasis on "upbringing" (vospitanie), which refers to learning's non-cognitive domains. These include moral or "patriotic" education (see Rapoport 2009), which is not measured by international tests or national examinations.

The experts interviewed presented several QAE issues and pondered the solutions leading to new ideas for development. These ideas were not necessarily antithetical to "nostalgic" views - the former might also complement the latter. The notion of education quality embodied in international assessments, especially PISA, was seen as providing a scientific basis for improvement of quality through testing students' problem-solving skills. As a counterbalance, the importance of Russian cultural heritage, which values literature and reading for non-instrumental purposes, was also emphasised (see also Piattoeva \& Gurova 2018). It is noteworthy that the 1998 OECD report on Russia strived for a balance between acknowledging positive aspects of the Russian pedagogical heritage, including assessment practices, and criticising the same pedagogy as unsuited to the needs of a market economy and international competitiveness (OECD 1998: pp. 9, 16, 91, 99-103). 
Some experts argued that assessment should be more independent of teachers, because it was the results of their work that was being assessed. At the same time, there will be a need to familiarise teachers with the new methods of QAE and motivate them to use their results as feedback to stimulate their own professional work. Furthermore, the high-stakes nature of the national examinations at grades 9 and 11 was criticised as narrowing the concept of quality to what the SFA and USE measured. Instead of focusing on only one type of uniform measurement of learning, there should be a diversified system of QAE which comprised both quantitative and qualitative components (such as essays and portfolios), covering a wide range of learning domains in the curriculum and extracurricular activities. The experts who voiced an opinion on the ranking of schools based on QAE results and the resulting competitive atmosphere did not question it as such but called for more analysis of differences in learning achievement between schools and regions which would make it possible to devise corrective measures to support low-achievers.

\section{Conclusions}

Our analysis has shown that history sets boundaries but also provides sources of political legitimation to the three countries' future imaginaries. Based on the data from Brazil, it can be stated that there is no symbolic period in the history of the country in which interviewees or the examined documentary material locate the future. In contrast, the Chinese authorities, in justifying future projects, appear to rely on the nostalgic idea of restoring the status the country has lost. The data on Russia also suggest that the recent past has coloured ideas of the strengths of Soviet and pre-Soviet pedagogy. However, the nostalgic Chinese and Russian views differ substantially in their semantics from the fifth archetype described at the beginning of this chapter; instead of looking back to traditional or simpler forms of education, the value placed on national traditions in China and Russia is combined with the ambitious aim of improving the quality of the national education systems.

In examining the current factors affecting the images of future developments of education and QAE in the three countries, we found that education has been regarded as a central tool for socio-economic development, especially in Brazil, regardless of transfers of power. In Russia, the need for continuing education reforms is generally acknowledged, although views on how such reforms are implemented vary. In China, rapid economic growth and an understanding of education as its key element have contributed to the universalisation of basic education and projects to improve the quality of education. However, circumstances and trends such as political discontinuity in Brazil, administrative arbitrariness in Russia, or the rigidity of governance and legislation in China are features which continue to complicate education's future directions.

Along with history and present circumstances, the future is influenced by many often concurrent and rival views, which are often presented in the forms of plans, scenarios, or visions. These views could be conceived of as factors 
which "pull" human beings towards particular futures. The archetypes presented at the beginning of this chapter attempt to categorise some initial views of education futures, which, instead of a strict theoretical framework, serve as a reflective basis for this chapter's analysis (Inayatullah 2008). Future research on QAE in education is especially challenging from this perspective, because the core of the education system is people's ability to acquire new knowledge and on this basis to influence future trends and the emergence of new societal ideas.

In searching our data, we found that Brazilian views reflected a combination of several archetypes. While "evolution and progress" is the main - implicit and explicit - stance in Brazilian political and social culture (the Brazilian flag's motto is "order and progress"), its justification is most frequently tied to idealistic education and social ideals ("Gaia"). If we understand "globalism" as conveyed by international QAE practices and policies, and as the expected and desired growing participation of civic society in education debates and decisions, it might be said that in addition to the intersection of the first two archetypes - which largely define the Brazilian views - globalism is also gradually shaping the Brazilian imaginary.

In China, as previous research suggests, visions expressed at the state level may differ significantly from individual views of the future. The experts interviewed for this study shared their views on the need to reform school curricula and develop schools as modern institutions, the purpose of which was to promote the overall development of children and adolescents. Continuous development and progress is also the thread of the current national Outline. However, the idea of education as a source of national rejuvenation reflects a nostalgia stated in the Outline but which was not communicated by the Chinese interviewees. Although it is impossible to exhaustively demonstrate any competing or deviating images of the future based on a small number of interviews, our analysis suggests that the views of the interviewed experts on the current state and future of QAE in education, especially on the supervisory system, differs from the stipulations of the Outline. Furthermore, the globalist archetype of the future seems unfamiliar in the Chinese context, although China is actively seeking to identify best practices abroad and has lowered the threshold for cooperation with international actors. Nor was the idea of schools as gardens of learning reflected in responses in the Chinese documents and interviews analysed in this study. However, this does not mean that the idea of learning as a garden is not present elsewhere in Chinese education thinking; the metaphor of the teacher as a gardener dedicated to his or her work is common in China.

The theme arising from our Russian data centred on two opposing, or as this research suggests, somewhat complementary forces: Western assessment systems measuring quality as cognitive competences and the survival of the pedagogical and moral education developed in pre-Soviet and Soviet times. The Russian interviewees reflected on how the education system might be developed in a balanced way, with traditional values and new methods for evaluating learning achievements complementing each other. They emphasised that the development of education should not focus only on one-sided instrumental or 
cognitive learning and the evaluation of learning outcomes but also on the cultural and moral upbringing of children and youth. Thus, nostalgia in Russian education does not seek a return to previous systems; rather, it seeks to retain some elements considered important in national curricula, teaching, and QAE practices. In emphasising the importance of educating civilised individuals and the significance of non-cognitive learning outcomes, the ideals of the Russian education system seem closer to those of the Brazilian system than those of the Chinese system.

Altogether, our study showed that even if only some of the archetypes or their variants can be found in the research data, examining them may help to distinguish new nuances, issues, and views which may affect education's future policies and governance.

\section{Bibliography}

Adam, B. (2010). History of the future: Paradoxes and challenges. Rethinking History, 14(3), 361-378.

Américo de Figueiredo Porto, C., Marques, E., \& Befort Andrade Santos, A. (2010). Prospective in Brazil: The power to build the future. Technological Forecasting \& Social Change, 77, 1550-1558.

Andersson, J. (2012). The great future debate and the struggle for the world. American Historical Review, 117(5), 1411-1430.

Andersson, J., \& Rindzevičiūtè, E. (Eds.). (2016). The Struggle for the Long-Term in Transnational Science and Politics: Forging the Future. New York, NY \& London: Routledge.

Bacon, E. (2012). Writing Russia's future: Paradigms, drivers, and scenarios. Europe-Asia Studies, 64(7), 1165-1189.

Baird, J.-A., Johnson, S., Hopfenbeck, T. N., Isaacs, T., Sprague, T., Stobart, G., \& Yu, G. (2016). On the supranational spell of PISA in policy. Educational Research, 58(2), 121-138.

Biesta, G., \& Osberg, D. (2010). Complexity, education and politics from the inside-out and the outside-in: An Introduction. In D. Osberg \& G. Biesta (Eds.), Complexity Theory and the Politics of Education (pp. 1-4). Rotterdam: Sense Publishers.

Blackspear, S. (2012). The policy impact of PISA: An exploration of the normative effect of international benchmarking in school system performance (OECD Education Working Papers, No. 71). Paris: OECD.

Boguslavskii, M. V., \& Lelchitskii, I. D. (2016). Modern development strategies of the Russian education in the conditions of the information society. SHS Web of Conferences, 29, 01010 .

Braathen, E., \& Kasahara, Y. (2015). Brazil, land of future? Conservative development strategy and urban challenge. In A. Hansen \& U. Wethal (Eds.), Emerging Economies and Challenges to Sustainability: Theories, Strategies and Local Sustainabilities (pp. 135-148). London \& New York, NY: Routledge.

Brasil, Câmara dos Deputados. (2014). Plano Nacional de Educação 2014-2024, Lei n. 13.005, de 25 de Junho de 2014, que aprova o Plano Nacional de Educação (PNE) e dá outras providências. Atualizada em 1/12/2014 [National Plan of Education 2014-2024, Law no. 13.005, 25 June 2014, which passes the National Plan of Education (PNE) and provides other guidelines. Updated on 1 December 2014]. Brasília: Câmara dos Deputados, Centro de 
Documentação e Informação, Coordenação Edições Câmara. Retrieved from www.plan alto.gov.br/ccivil_03/_ato2011-2014/2014/lei/113005.htm

Brasil, Ministério da Educação/Secretaria de Articulação com os Sistemas de Ensino (MEC/ SASE). (2014). Planejando a Próxima Década: Conhecendo as 20 Metas do Plano Nacional de Educação [Planning the Next Decade: Knowing the 20 Goals of the National Plan of Education]. Retrieved August 25, 2016, from http://pne.mec.gov.br/images/pdf/pne_con hecendo_20_metas.pdf

Bussey, M., Inayatullah, S., \& Milojevic, I. (Eds.). (2008). Alternative Educational Futures: Pedagogies for Emergent Worlds. Rotterdam/Taipei: Sense Publishers.

Cairney, P., \& Geyer, R. (2015). Introduction. In R. Geyer \& P. Cairney (Eds.), Handbook on Complexity and Public Policy (pp. 1-15). Cheltenham: Edward Elgar Publishing.

Callahan, W. (2016). China 2035: From the China dream to the world dream. Global Affairs, 2(3), 247-258.

Centeno, V. G., Kauko, J., \& Candido, H. H. D. (2017). Quality assurance and evaluation through Brazilian lenses: An exploration into the validity of umbrella concepts. Comparative Education, published on-line. Retrieved from http://dx.doi.org/10.1080/03050068. 2017.1348084

Coronil, F. (2011). The future in question: History and Utopia in Latin America (19892010). In G. Calhoun \& G. Derluguian (Eds.), Business as Usual: The Roots of the Global Financial Meltdown (pp. 231-292). New York, NY \& London: New York University Press.

Cruz, S. O. (2015). Alternative futures of global governance: Scenarios and perspectives from the Global South. Foresight, 17(2), 125-142.

Deng, Z. (2011). Confucianism, modernization and Chinese pedagogy: An introduction. Journal of Curriculum Studies, 43(5), 561-568.

de Oliveira, R. P., \& de Araujo, G. C. (2005). Qualidade do ensino: uma nova dimensão da luta pelo direito à educação [Educational quality: A new dimension of the struggle for the right to education]. Revista Brasileira de Educação, 28, 5-23.

Fonseca, M. (2009). Políticas públicas para a qualidade da educação brasileira: entre o utilitarismo econômico e a responsabilidade social [Public policies for the quality of Brazilian education: Between economic utilitarianism and social responsibility]. Cadernos CEDES, 29, 153-177.

Gouveia, A. B., \& de Souza, Â. R. (2013). Efetividade da política para o ensino fundamental em municípios Brasileiros [Policy effectiveness for elementary education in Brazilian municipalities]. Cadernos Pesquisa, 43(150), 836-855.

Government of Russia. (2012). Gosudarstvennaia programma Rossiiskoi Federatsii "Razvitie obrazovaniia" na 2013-2020 gody [State programme of the Russian Federation "Development of education" for 2013-2020]. Retrieved December 10, 2016, from http://gov ernment.ru/en/docs/3342

Graziano, X. (2011). Semeando o futuro: 80 medidas estruturantes do governo FHC [Sowing the future: 80 structuring measures of FHC government]. Fundação Fernando Henrique Cardoso. Retrieved May 11, 2017, from http://fundacaofhc.org.br/files/pdf/80-medidasestruturantes-governo-fhc.pdf

Gu, M. (2010). A blueprint for educational development in China: A review of "The National Guidelines for Medium- and Long-Term Educational Reform and Development (2010-2020)". Frontiers of Education in China, 5(3), 291-309.

Hoffman, J. (2013). China's search for the future: A genealogical approach. Futures, 54, 53-67. Inayatullah, S. (1990). Deconstructing and reconstructing the future: Predictive, cultural and critical epistemologies. Futures, 22(2), 115-141. 
Inayatullah, S. (2008). Mapping educational futures. In M. Bussey, S. Inayatullah, \& I. Milojevic (Eds.), Alternative Educational Futures: Pedagogies for Emergent Worlds (pp. 13-39). Rotterdam/Taipei: Sense Publishers.

Johnson, D. (2010). Educational reform in Russia: Culture, context and worldview. In D. Johnson (Ed.), Politics, Modernisation and Educational Reform in Russia From Past to Present (pp. 7-16). Southampton, Oxford Symposium Books.

Klein, R. (2006). Como está a educação no Brasil? O que fazer? [How is education in Brazil? What to do?] Ensaio: Avaliação de Políticas Públicas Educacionais, 14(51), 139-172.

Krickovic, A. (2014). Imperial nostalgia or prudent geopolitics? Russia's efforts to reintegrate the post-Soviet space in geopolitical perspective. Post-Soviet Affairs, 30(6), 503-528.

Lula da Silva, L. I. (2013). n.t. [Lula da Silva speech to French entrepreneurs on the 21 March 2013, French consular residence]. Retrieved May 11, 2017, from https://saopaulo. consulfrance.org/Ex-presidente-Lula-convidado-de ; full speech in: www.institutolula. org/nao-existe-nenhum-pais-com-a-perspectiva-de-futuro-que-o-brasil-tem-diz-lula-aempresarios-franceses

Masini, E. B. (1993). Why Future Studies? London: Grey Seal.

Milojevic, I. (2005). Educational Futures: Dominant and Contesting Visions. London \& New York, NY: Routledge.

Morgan, W. J., \& Kliucharev, G. A. (2012). Higher education and the post-Soviet transition in Russia. European Journal of Education, 47(1), 3-8.

n.a. (2015). Uma ponte para o futuro [A bridge to the future], Brasília, 29 de Outubro de 2015. Fundação Ulysses Guimarães/PMDB. Retrieved May 11, 2017, from http://pmdb. org.br/wp-content/uploads/2015/10/RELEASE-TEMER_A4-28.10.15-Online.pdf

OECD. (1998). Review of National Policies for Education - the Russian Federation. Paris: OECD.

Ogilvy, J. (2004). Creating Better Futures: Scenario Planning as a Tool for a Better Tomorrow. New York, NY: Oxford University Press.

Oliveira, R. P. d. (2007). Da universalização do ensino fundamental ao desafio da qualidade: uma análise histórica [From the universalisation of elementary education to the challenge of education]. Educação E Sociedade, 28(100), 661-690.

Outline of China's National Plan for Medium and Long-Term Education Reform and Development. (2010-2020). Retrieved May 29, 2017, from http://planipolis.iiep.unesco.org/ sites/planipolis/files/ressources/china_national_long_term_educational_reform_develop ment_2010-2020_eng.pdf

Pavlova, M. (2010). The modernization of education in Russia. In D. Johnson (Ed.), Politics, Modernisation and Educational Reform in Russia From Past to Present (pp. 59-70). Southampton: Oxford Symposium Books.

Piattoeva, N., \& Gurova, G. (2018). Domesticating international assessments in Russia: Historical grievances, national values, scientific rationality and education modernization. In C. Alarcón \& M. Lawn (Eds.), Assessment Cultures: Historical Perspectives (pp. 87-110). Frankfurt am Main: Peter Lang.

Pierson, P. (2000). Increasing returns, path dependence, and the study of politics. The American Political Science Review, 94(2), 251-267.

Plank, D. N. (1990). The politics of basic education reform in Brazil. Comparative Education Review, 34(4), 538-559.

Postiglione, G. A. (2015). Research universities for national rejuvenation and global influence: China's search for a balanced model. Higher Education, 70(2), 235-250.

Rapoport, A. (2009). Patriotic education in Russia: Stylistic move or a sign of substantive counter-reform? The Educational Forum, 73(2), 141-152. 
Rousseff, D. (2014). Dilma afirma que educação é passaporte para futuro do Brasil [Dilma affirms that education is the passport for Brazil's future]. In Luciano (Ed.), No café com a Presidenta. Retrieved May 11, 2017, from www.brasil.gov.br/educacao/2014/01/ dilma-afirma-que-educacao-e-o-passaporte-para-o-futuro-do-brasil

Saviani, D. (1996). Política e Educação no Brasil [Policy and Education in Brazil] (3rd ed.). Campinas: Cortez/Autores Associados.

Schilling, E. (2008). Future concepts in Russia and Germany: Different approaches to planning in the global society. Twenty-First Century Society, 3(2), 131-142.

Schleicher, A., \& Zoido, P. (2016). The policies that shaped PISA and the policies that PISA shaped. In K. Mundy, A. Green, B. Lingard, \& A. Verger (Eds.), The Handbook of Global Education Policy (pp. 374-384). Chichester: John Wiley \& Sons.

Slaughter, R. (2002). Futures studies as an intellectual and applied discipline. In J. A. Dator (Ed.), Advancing Futures: Future Studies in Higher Education (pp. 91-108). Westport: Praeger.

Wjuniski, B. S. (2013). Education and development projects in Brazil (1930-2008): Political economy perspective. Brazilian Journal of Political Economy, 33(1), 146-165.

Xin, T., \& Kang, C. (2012). Qualitative advances of China's basic education since reform and opening up. Chinese Education and Society, 45(1), 42-50.

Yang, L. (2014). Implementation of China's rejuvenation through knowledge. In K. Shao \& $\mathrm{X}$. Feng (Eds.), Innovation and Intellectual Property in China: Strategies, Contexts and Challenges (pp. 53-79). Edward Elgar Publishing: Cheltenham.

Yuan, Z. (2013). China: Promoting equity as a basic education policy. In Y. Wang (Ed.), Education Policy Reform Trends in G20 Members (pp. 359-375). Berlin: Springer-Verlag.

Yurchak, A. (1997). The cynical reason of late socialism: Power, pretense and the Anekdot. Public Culture, 2(9).

Zarpellon, S. C. (2011). Continuidade e descontinuidade administrativa de programas e projetos econômicos e sociais: um ensaio sobre fatores que contribuem para esse fenômeno na região centro-sul do Paraná, Brasil [Administrative continuity and discontinuity of economic and social programmes and projects: An essay about the factors that contribute to the phenomenon in the south-central region of Paraná, Brazil]. In III Congresso Iinternacional de Educação de Ponta Grossa. Anais do CIEPG (Vol. 1, pp. 1-18). Ponta Grossa: UEPG. Zweig, S. (1941). Brazil: Land of the Future. New York, NY: The Viking Press. 